\title{
FIDUCIARY DUTIES AND RUPA: AN INQUIRY INTO FREEDOM OF CONTRACT
}

\author{
J. DENNIS HYNES*
}

INTRODUCTION

The Revised Uniform Partnership Act (1994) ("RUPA") ${ }^{1}$ revisits the topic of the fiduciary relationship among partners in an innovative and controversial way. Among other things, ${ }^{2}$ RUPA section 404 establishes a comprehensive ${ }^{3}$ definition of partnership fiduciary duties. ${ }^{4}$ It includes an express recognition

\footnotetext{
Copyright 191995 by Law and Contemporary Problems

* Professor of Law, University of Colorado.
}

The author is indebted to Professor Clifford Calhoun, who reviewed an earlier draft of this article and made a number of valuable suggestions. The helpful assistance of my research assistants, Scott Renner and Steve Perfrement, is gratefully acknowledged.

1. Uniform Partnership Act (1994) [hereinafter RUPA or the Act). Although the word "revised" is not in the official title to the 1994 Act, reference to it as RUPA is widespread in literature on the Act, in part for its convenience, and it will be referred to as RUPA in this article. RUPA is contained in the 1995 Supplementary Pamphlet to 6 U.L.A.

There are three versions of RUPA, promulgated by the National Conference of Commissioners on Uniform State Laws ("NCCUSL") in 1992, 1993, and 1994. All were passed as uniform acts in a period of three consecutive years, an event unprecedented in NCCUSL history.

2. As will be discussed later, infra text accompanying notes 14-18, the framers of RUPA have classified as nonfiduciary a number of obligations that in prior law were included in the fiduciary concept.

3. The Uniform Partnership Act (1914) (the "UPA") is the predecessor statute to RUPA. UNIF. PARTNERSHIP ACT, 6 U.L.A. 1 (1969). The UPA merely hints at fiduciary duties in its $\$ \S 19,20$, and 21 (the only reference to the word "fiduciary" in the UPA is contained in the title to $\$ 21$ ), and leaves it to the common law to develop the concept.

4. RUPA $\$ 404$ reads as follows:

\section{SECTION 404. GENERAL STANDARDS OF PARTNER'S CONDUCT}

(a) The only fiduciary duties a partner owes to the partnership and the other partners are the duty of loyalty and the duty of care set forth in subsections (b) and (c).

(b) A partner's duty of loyalty to the partnership and the other partners is limited to the following:

(1) to account to the partnership and hold as trustee for it any property, profit, or benefit derived by the partner in the conduct and winding up of the partnership business or derived from a use by the partner of partnership property, including the appropriation of a partnership opportunity;

(2) to refrain from dealing with the partnership in the conduct or winding up of the partnership business as or on behalf of a party having an interest adverse to the partnership; and

(3) to refrain from competing with the partnership in the conduct of the partnership business before the dissolution of the partnership.

(c) A partner's duty of care to the partnership and the other partners in the conduct and winding up of the partnership business is limited to refraining from engaging in grossly negligent or reckless conduct, intentional misconduct, or a knowing violation of the law.

(d) A partner shall discharge the duties to the partnership and the other partners under this [Act] or under the partnership agreement and exercise any rights consistently with the obligation of good faith and fair dealing. 
of the unique position of a partner, who acts both as a fiduciary of others and as a self-interested co-owner of the business seeking personal profit. ${ }^{5}$ RUPA also introduces a comprehensive duty of good faith and fair dealing into the statutory law of partnership. ${ }^{6}$ In addition, the waivability of these duties in the partnership context, never before addressed by statute, is covered in section 103 of RUPA, which prohibits waiver of the duties described in section 404.?

(e) A partner does not violate a duty or obligation under this [Act] or under the partnership agreement merely because the partner's conduct furthers the partner's own interest.

(f) A partner may lend money to and transact other business with the partnership, and as to each loan or transaction the rights and obligations of the partner are the same as those of a person who is not a partner, subject to other applicable law.

(g) This section applies to a person winding up the partnership business as the personal or legal representative of the last surviving partner as if the person were a partner.

5. RUPA § 404(e), 6 U.L.A. at 313 (Supp. 1995); see Allan W. Vestal, Fundamental Contractarian Error in the Revised Uniform Partnership Act of 1992, 73 B.U. L. REV. 523, 535 (1993) ("In one stroke of the pen the drafters have made the partners adversaries, whereas before they were bound by 'the duty of the finest loyalty,' not merely 'the common standards of competitors."' (notes omitted)). See also, from a different perspective, Robert W. Hillman, Private Ordering Within Partnerships, 41 U. MIAMI L. REV. 425, 458 (1987) ("If partners truly are fiduciaries, they are a unique species of this group and cannot be subjected to traditional standards applicable to other types of fiduciaries.... The fiduciary as joint owner, although not unknown, is something of a contradiction in terms. Partners, on the other hand, are always joint owners. The principal objective of each is to maximize personal gain. (note omitted)").

6. RUPA $\S 404$ (d), 6 U.L.A. at 313 (Supp. 1995). The UPA, the predecessor of RUPA, contains a requirement of good faith, but it is not comprehensive. UPA $\$ 31(1)$ (d) mandates good faith (using the words "bona fide") for the expulsion of a partner in accordance with a power conferred by the partnership agreement. UPA § 31, 6 U.L.A. 376 (1969). No other section of the UPA contains any such requirement and there is no general provision equivalent to RUPA $\S 404(d)$. Good faith is not defined in the UPA. It has been narrowly interpreted by courts to require a fair evaluation of the expelled partner's interest but not to require cause, a hearing, or other limitations. See J. Dennis Hynes, The Revised Uniform Partnership Act: Some Comments on the Latest Draft of RUPA, 19 FLA. ST. L. REV. 727, 740-50 (1992).

7. Section 103 reads as follows:

(a) Except as otherwise provided in subsection (b), relations among the partners and between the partners and the partnership are governed by the partnership agreement. To the extent the partnership agreement does not otherwise provide, this [Act] governs relations among the partners and between the partners and the partnership.

(b) The partnership agreement may not:

(1) vary the rights and duties under Section 105 except to eliminate the duty to provide copies of statements to all of the partners;

(2) unreasonably restrict the right of access to books and records under Section 403(b);

(3) eliminate the duty of loyalty under Section $404(\mathrm{~b})$ or Section $603(\mathrm{~b})(3)$, but (i) the partnership agreement may identify specific types or categories of activities that do not violate the duty of loyalty, if not manifestly unreasonable or (ii) all of the partners or a number or percentage specified in the partnership agreement may authorize or ratify, after full disclosure of all material facts, a specific act or transaction that would violate the duty of loyalty;

(4) unreasonably reduce the duty of care under Section 404 (c) or $603(\mathrm{~b})(3)$;

(5) eliminate the obligation of good faith and fair dealing under Section 404(d), but the partnership agreement may prescribe the standards by which the performance of the obligation is to be measured, if the standards are not manifestly unreasonable;

(6) vary the power to dissociate as a partner under Section 602(a), except to require the notice under Section 601(1) to be in writing;

(7) vary the right of a court to expel a partner in the events specified in Section 601(5);

(8) vary the requirement to wind up the partnership business in cases specified in Section 801(4), (5), or (6); or

(9) restrict rights of third parties under this [Act]. 
It is this subject, the waivability of duties owed by partners to each other, that is the primary focus of this article. The issue of waivability is difficult and troubling. Exploring it raises fundamental questions about the nature of the partnership relationship. Strong and appealing arguments can be made on both sides of the issue, as will be developed below.

The thesis of this article is that the approach taken by RUPA endorses too great an invasion of the principle of freedom of contract among partners, who as contracting parties ordinarily do not occupy positions of unequal bargaining power. A change in the language of RUPA is proposed with the goal of expanding freedom of contract without, however, abandoning the requirement of good faith. ${ }^{8}$

Part II of this article explains the innovations made by RUPA and the history of how they were chosen over the alternatives. Part III examines the nature of the partnership relationship and weighs the costs and benefits of mandatory duties. Part IV sets forth an alternative to eliminating mandatory duties, using an unconscionability standard to evaluate partnership agreements that alter partnership duties.

II

The Changes Made By RuPa

\section{A. Fiduciary Duties Under RUPA}

Section 404 of RUPA, entitled General Standards of Partner's Conduct, defines fiduciary duties among partners. It states that "[t]he only fiduciary duties a partner owes to the partnership and the other partners are the duty of loyalty and the duty of care set forth in subsections (b) and (c)." ${ }^{9}$ This language is significant in several respects.

RUPA § 103, 6 U.L.A. at 288-89 (Supp. 1995).

Although the language of $\S 103$ cross-refers only to $\S 404$ (b)-(d), those subsections constitute all of the duties established by $\$ 404$. Subsection (a) is merely an introductory section, and subsections (e)-(g) deal largely with exceptions to the duties described in (b)-(d). Id. $\$ 404,6$ U.L.A. at 313.

8. This article does not take issue with the decision to classify the duty of good faith and fair dealing as mandatory. In doing so, the drafters of RUPA followed the overwhelming trend to expressly articulate the duty of good faith as an implied term of all contracts. See U.C.C. § 1-203 (1989) ("Every contract or duty within this Act imposes an obligation of good faith in its performance or enforcement."); MODEL BUSINESS CORP. ACT $\$ \$ 8.30$ (directors), .42 (officers) (1983); UNIF. LTD. LIAB. CO. ACT $\$ 409$ (d) ("A member shall discharge the duties to a member-managed limited liability company and its other members ... consistently with the obligation of good faith and fair dealing."); RESTATEMENT (SECOND) OF CONTRACTS $\$ 205$ (1981) ("Every contract imposes upon each party a duty of good faith and fair dealing in its performance and its enforcement.").

Not all of these authorities expressly declare the prescribed duty of good faith to be mandatory, but it seems safe to assume that it would be so characterized in litigation arising under most of these authorities. This article focuses, instead, on defining good faith in the partnership context, something that those drafting RUPA chose not to do. See infra text accompanying notes 85-98 for a discussion of this topic.

9. RUPA § 404(a), 6 U.L.A. at 313. 
First, the choice of the word "only" is curious. It seems odd to confine a description of fiduciary duties in such fashion. One conceives of fiduciary duties as not fully defined, and perhaps incapable of full definition, considering the breadth of the underlying principles governing relationships of trust and confidence as well as the seemingly endless variety of situations that can generate problems at the boundaries of even well-accepted principles. ${ }^{10}$ Thus, one would expect to see a word like "includes" instead of "only" in recognition of the inherent inability of the law to draw clear, sharp lines in defining fiduciary duties. Such wording would leave room for modification and expansion of fiduciary duties as circumstances present themselves.

The drafters of RUPA apparently felt that the value of a definition of fiduciary duties that would leave room for expansion and reformulation of underlying principles was outweighed by the competing value of certainty and reliability of partnership agreements. ${ }^{11}$ They seemed concerned that an attorney may feel particularly uncertain about the reliability of a partnership agreement when drafting provisions addressing the relationship among the partners. ${ }^{12}$ One source of this uncertainty is the fear that courts may create new fiduciary duties or stretch existing fiduciary duties into unrecognizable

10. For a discussion of this concept, see Deborah A. DeMott, Beyond Metaphor: An Analysis of Fiduciary Obligation, 1988 DUKE L.J. 879, 879:

Fiduciary obligation is one of the most elusive concepts in Anglo-American law. Applicable in a variety of contexts, and apparently developed through a jurisprudence of analogy rather than principle, the fiduciary constraint on a party's discretion to pursue self-interest resists tidy categorization. Although one can identify common core principles of fiduciary obligation, these principles apply with greater or less force in different contexts involving different types of parties and relationships. Recognition that the law of fiduciary obligation is situation-specific should be the starting point for any further analysis.

11. The language of the comment to $\S 404$ does not describe the policy underlying the use of the word "only." Perhaps the statements quoted immediately below from an article describing the new Act, authored by the reporters for RUPA, will serve as an explanation. The context is a discussion of the policy behind the decision to specify in detail what is meant by the duty of loyalty. See Donald $\mathrm{J}$. Weidner \& John W. Larson, The Revised Uniform Partnership Act: The Reporters' Overview, 49 BUS. LAW. 1, 23 (1993):

It was suggested [in meetings where RUPA was drafted] that overly broad judicial language has left practitioners uncertain about whether their negotiated agreements will be voided. It was said that lawyers and their clients want to be able to negotiate transactions, reduce their agreements to writing, and have some comfort that those agreements will not be undone by "fuzzy" notions of fiduciary duties.

12. See Donald J. Weidner, Three Policy Decisions Animate Revision of Uniform Partnership Act, 46 Bus. LAW. 427, 462 (1991) [hereinafter Three Policy Decisions]:

RUPA [ $\$ 404$ (b)] appears to have been motivated in part by a sense that vague, broad statements of a powerful duty of loyalty cause too much uncertainty. It was suggested that, even if there were no bad holdings, overly broad judicial language has left practitioners uncertain about whether their negotiated agreements will be voided.

Three Policy Decisions is one of a series of articles Dean Weidner, as reporter for RUPA, has written on RUPA. See supra note 11 and infra notes 13 and 50 . His articles, containing balanced and thoughtful discussion of the problems faced and decisions made by those drafting the Act, provide a rich contribution to the literature on RUPA. 
form, undermining the parties' true understanding as expressed in the partnership agreement. ${ }^{13}$

Second, RUPA does not classify as fiduciary duties some duties that have been recognized elsewhere as fiduciary in nature, such as the duty of good faith and fair dealing, ${ }^{14}$ and the duty to furnish information to fellow partners. ${ }^{15}$ Instead, the duty of good faith and fair dealing is described as an obligation limited to characterizing the manner of performance of other obligations. ${ }^{16}$

13. See Donald J. Weidner, The Revised Uniform Partnership Act Midstream: Major Policy Decisions, 21 U. TOL. L. REV. 825, 856 (1990) ("It was said that practicing attorneys want to be able to reach a deal, put it down on paper and know that it will not be undone by the application of fiduciary duties.").

It seems safe to conclude that the decision to use the word "only" is a strong endorsement of the principle of achieving as much certainty and reliability as possible in partnership agreements. This approach is understandable, at least as an abstract proposition. Who can quarrel with the policy of providing certainty and reliability to partnership contracts, within the framework of limitations applicabie to all contracts?

14. The duty of good faith is classified as a fiduciary duty by some authorities. See, e.g., 2 ALAN R. BROMBERG \& LARRY E. RIBSTEIN, BROMBERG AND RIBSTEIN ON PARTNERSHIP \& 6.07, at 6:68 (1988) ("The main elements of the partner's fiduciary duties are well recognized: utmost good faith, fairness, and loyalty.").

15. Weidner \& Larson, supra note 11, at 25 :

The section 404 assertion that it contains an exclusive list of the fiduciary duties of partners is subject to one major qualification: the information and consultation rights of partners remain, as they were under the UPA, separately stated. RUPA includes obligations that have been considered fiduciary in nature without describing them as fiduciary duties.

(note citing $\S \S 19-20$ of the UPA omitted).

16. The obligation is to discharge the duties to the partnership and the other partners under RUPA or under the partnership agreement "consistently with the obligation of good faith and fair dealing." RUPA § 404(d), 6 U.L.A. at 313 (Supp. 1995). The intent to treat this obligation as independent of fiduciary duties is made clear in the comment to $\S 404$, which states in relevant part:

The obligation of good faith and fair dealing is a contract concept, imposed on the partners because of the consensual nature of a partnership. It is not a fiduciary duty arising out of the partners' special relationship. Nor is it a separate and independent obligation. It is an ancillary obligation which is dependent on the existence of another duty arising under the partnership agreement or the Act.

Id. $\$ 404 \mathrm{cmt} ., 6$ U.L.A. at 315 .

An explanation for this approach to the duty of good faith, which in earlier drafts of RUPA was classified as a fiduciary duty (see, e.g., the 1991 draft of RUPA $\$ 404$, stating, "The only fiduciary duties a partner owes to the partnership and the other partners are the duty of good faith and fair dealing, the duty of loyalty, and the duty of care, as set forth in this section."), is contained in the comments to $\S 404$ of the 1992 draft of RUPA.

The previous draft [Section 404(a)] contained a separate and independent "duty of good faith and fair dealing [as a fiduciary duty]." This was deleted at the insistence of the ABA Ad Hoc Committee. The ABA's objection was that the duty of good faith is neither a fiduciary duty nor a separate and independent obligation. Good faith is, the ABA explains, a concept of general contract law which partners owe each other by virtue of the partnership agreement, not by virtue of the special relationship of partners. The characterization of the duty of good faith and fair dealing as a separate and independent fiduciary duty was confusing and would have generated considerable mischief, according to the Ad Hoc Committee.

RUPA § $404 \mathrm{cmt}$. (1992). 
The duty to provide information is separately described, with no apparent relation to its fiduciary genesis. ${ }^{17}$

Again, the policy of narrowing the definition of fiduciary duties and thus increasing the reliability of agreements seems to underlie this decision. ${ }^{18}$

\section{B. Waivability of Fiduciary Duties}

One of the changes made by RUPA is the specification in section 103 of the rules in the Act that are mandatory, with the rest of the rules classified as default rules. ${ }^{19}$ Among others, all fiduciary duties and the duty of good faith and fair dealing are classified as mandatory duties. ${ }^{20}$ This classification had been left ambiguous by the Uniform Partnership Act (the "UPA"), posing a problem for persons drafting partnership agreements. ${ }^{21}$

Section 103 not only clarifies what previously was ambiguous, it also can be read to enhance freedom of contract among partners. The drafters of RUPA made an effort to keep the list of mandatory rules as narrow as possible and to characterize all other provisions in the Act as default in nature. ${ }^{22}$ Considering

17. RUPA $\S 403(\mathrm{c})$ reads as follows:

(c) Each partner and the partnership shall furnish to a partner, and to the legal representative of a deceased partner or partner under legal disability:

(1) without demand, any information concerning the partnership's business and affairs reasonably required for the proper exercise of the partner's rights and duties under the partnership agreement or this [Act]; and

(2) on demand, any other information concerning the partnership's business and affairs, except to the extent the demand or the information demanded is unreasonable or otherwise improper under the circumstances.

RUPA $\S 403$ (c), 6 U.L.A. at 312 (Supp. 1995). The duty to provide information under $\S 403$ (c) is not included as a mandatory duty under $\$ 103$. This is curious because closely related duties, such as the duty to provide access to books and records under $\S 403(\mathrm{~b})$, are included within the sweep of $\S 103$. Id. $\$ 103(\mathrm{~b})(2), 6$ U.L.A. at 288.

18. See supra note 16, in particular the language referring to the ABA's objection. It is assumed that the phrase "considerable mischief" refers to contractual instability.

19. RUPA $\S 103 \mathrm{cmt} .1,6$ U.L.A. at 289 (Supp. 1995). If a rule is intended to apply regardless of the agreement of the partners, it is "mandatory." Id. If a rule in RUPA can be changed by agreement of the partners, it is a "default" rule. An example of a default rule is the rule in RUPA \& 401(i), specifying that "[a] person may become a partner only with the consent of all of the partners." Id. $\$ 401$ (i), 6 U.L.A. at 309. Partners can cede the choice of future partners to a majority vote of the partners, or to the managing partners, or otherwise, if so desired. Id. $\$ 103$ (a), 6 U.L.A. at 288.

20. Id. § 103(b)(3)-(5), 6 U.L.A. at $288-89$.

21. An example of this is provided in Weidner, Three Policy Decisions, supra note 12, at 453-54: [Consider] UPA section 20, which provides without qualification that partners "shall render on demand true and full information of all things affecting the partnership to any partner. ..." Is an attempt to contract away this rule enforceable? ... Finally, consider the rights of partners on dissolution. UPA section 38(1), which governs "rightful" dissolution, applies "unless otherwise agreed." On the other hand, UPA section 38(2), which governs "wrongful" dissolutions, contains no qualifier. Are the wrongful dissolution provisions mandatory even though the rightful dissolution provisions are merely default rules?

22. Id. at 454 ("Mandatory rules governing the relations among partners are essentially parentalistic, and the Committee felt that, with only very limited exception, adults in nonconsumer transactions should be held to their agreements."). 
that, it seems almost ungenerous to criticize RUPA for not going far enough. ${ }^{23}$ Yet doubts can be raised about the decision to classify fiduciary duties as mandatory. ${ }^{24}$

As noted above, the intent of those drafting RUPA in creating a limited and exclusive definition of fiduciary duties was to enhance the reliability and certainty of partnership agreements, a worthy goal. ${ }^{25}$ The puzzling aspect of this, however, is the companion decision to deny partners the contractual freedom to define their relationship as they wish. This seems a curious contradiction. In one innovative and controversial move, RUPA denies courts the power to create new and different fiduciary duties, apparently in the interest of certainty. Yet in section 103, RUPA renders uncertain the efforts to draft an agreement in a way that tailors fiduciary duties to the partners' wishes. What happened to the goal of reliability of partnership agreements?

\section{The Drafting History of Sections 103 and 404}

The RUPA drafting committee prepared its early drafts on the assumption that the provisions addressing the fiduciary duties of care and loyalty were default rules. ${ }^{26}$ It consistently stated that the duty of good faith could not be eliminated entirely, however, ${ }^{27}$ and in the early drafts defined good faith as a fiduciary duty. ${ }^{28}$ In 1992 a final draft of RUPA was prepared for submission to the members of the National Conference of Commissioners on Uniform State

23. In addition to their effort to narrow the list of mandatory rules, those drafting RUPA also included language in $\S 103(\mathrm{~b})(3)$ and (5) allowing modification of the duty of loyalty and the duty of good faith and fair dealing if the modifying provisions in the partnership agreement are not "manifestly unreasonable," and language in $\S 103(b)(4)$ allowing modification of the duty of care if the partnership agreement does not "unreasonably" reduce it. RUPA § 103(b)(3)-(5), 6 U.L.A. at 288-89 (Supp. 1995). See infra part IV.A, developing the issues posed by such language.

24. One might ask why there should be any doubts about the decision to classify fiduciary duties as mandatory. Fiduciary duties occupy a unique and honored place in the law. As a result, contract provisions addressed to them are given special scrutiny in many jurisdictions. See infra text accompanying notes $73-84$, acknowledging that this approach has considerable merit, but raising arguments about the competing value of freedom of contract.

25. This does not mean that perfect certainty and reliability will ever be achieved, of course. But that truism does not undermine reasonable efforts to introduce as much certainty as possible for partnership agreements.

26. See RUPA \$\$ 20A, 20B (Part IV, First Draft of Possible New Statutory Language 1988) (defining the duties of care and loyalty and making it clear that the partners could "otherwise agree"). Subsequent drafts continued this approach. A special section devoted solely to the description of mandatory duties first appeared in the $1990 \mathrm{draft}$ as $\$ 4 \mathrm{x}$. Compare RUPA $\S 20 \mathrm{~A}, 20 \mathrm{~B}$ (Draft 1988) with RUPA \& 4x (Draft 1990). The 1991 Draft for Partial Approval, dated August 2, 1991, which was submitted to the membership of the NCCUSL for a first reading, does not include in its $\$ 105$ (now $\S 103$ ) the fiduciary duties of care and loyalty in its list of mandatory rules. RUPA $\S 105$ (Draft for Partial Approval 1991).

27. See RUPA \$ 20A(e) (Draft 1988) ("The partnership agreement may vary these general standards for partners with management rights under section 18(f), except that a partner's duty to act in good faith may not be abrogated by agreement.").

28. See, e.g., RUPA $\& 21$ (Draft for Discussion Only, with Prefatory Note and Comments, 1989). Section 21 is entitled "PARTNER ACCOUNTABLE AS A FIDUCIARY." Subsection (a) states, "A partner must act in good faith and in a manner he [or she] believes to be in the best interests of the partnership and the other partners in his [or her] conduct in relation to the partnership." 
Laws (the "NCCUSL") for the second and final reading for approval as a uniform act. This draft did not include fiduciary duties within its list of mandatory provisions in section $103 .{ }^{29}$ It also dropped the phrase "and fair dealing" from the duty of good faith and fair dealing, ${ }^{30}$ and no longer defined the duty of good faith as a fiduciary duty. ${ }^{31}$

1. A Thunderbolt From Berkeley. On July 27, 1992, just days prior to the second and final reading of RUPA, Professor Eisenberg ${ }^{32}$ sent a letter to the members of the NCCUSL. In his letter, he objected to the definition of the duty of loyalty as "narrow and restricted." 33 He also objected to the decision to drop the phrase "and fair dealing" from the duty of good faith in section $404{ }^{34}$ He wrote, "The present draft of Section 404 is, in my view, a travesty. It is incomprehensible to me that such a pinched and almost mean-spirited vision of the duty of loyalty would be proposed to you." 35

Professor Eisenberg then turned his attention to section 105 of the 1992 Draft (section 103 in RUPA), noting that the Draft permitted the complete elimination of the duty of loyalty. ${ }^{36}$ After observing that under the Revised Uniform Limited Partnership Act the fiduciary duties of general partners are in effect determined by UPA, he wrote:

29. RUPA $\S 103$ (Draft for Approval at the August 1992 Meeting of NCCUSL, with Comments,

30. The phrase "and fair dealing" had been added in the 1990 Draft of RUPA. RUPA $\S 21$ (Draft 1990).

31. RUPA § 404(d) (Draft 1992).

32. Professor Melvin Aron Eisenberg is a member of the law faculty at the University of California School of Law at Berkeley.

33. The duty of loyalty was defined in the 1992 draft as follows:

Section $404($ b). A partner's duty of loyalty to the partnership and the other partners is limited to the following:

(1) to account to the partnership and hold as trustee for it any property, profit, or benefit derived by the partner, without the consent of the other partners, in the conduct and winding up of the partnership business or from a use by the partner of partnership property;

(2) to refrain from dealing with the partnership on behalf of a party having an interest adverse to the partnership without the consent of the other partners; and

(3) to refrain from competing with the partnership without the consent of the other partners.

RUPA § 404 (b) (Draft 1992).

Professor Eisenberg also stated that, "[t]o begin with, the duty of loyalty has traditionally been an open concept. For one thing, the duty of loyalty rests in large part on social understandings of fairness and morality, and those understandings are always changing. For another, even at any given moment it is impossible to capture all the meaning of the duty of loyalty in a few canonical words, no matter how well chosen." Letter from Melvin A. Eisenberg to the NCCUSL 2 (July 27, 1992) (on file with author).

34. With regard to the duty of fair dealing, Professor Eisenberg stated, "Because the duty of fair dealing has been dropped from both Section 404 and Section 103, the new Draft permits the complete elimination of the duty of loyalty. Under the new Draft, it is possible to contract out of all duties of fairness, fair dealing, and disclosure." Letter from Melvin A. Eisenberg to the NCCUSL, supra note 33, at 6 (emphasis added).

35. Id. at 4 .

36. Id. at 5 . 
Even if one could somehow believe that in a general partnership the partners can make well-informed bargains about waiving the duty of loyalty, it would be at best a bad joke to believe that limited partners in a publicly held limited partnership can bargain about such provisions in any meaningful sense. ${ }^{37}$

Professor Eisenberg also referred to the arguments he had made to the members of the NCCUSL in a letter he had written on July 17, 1992. In that letter, he argued that, owing to the uncertain and fluid nature of many partnerships, it is almost impossible to anticipate ways in which a provision overriding fiduciary duties can be abused by an opportunistic partner, and thus either section 103 should be dropped altogether, returning to the format of the UPA, or fiduciary rules should be included as mandatory duties under section $103 .^{38}$

2. The Response by the NCCUSL. The Eisenberg letter had a powerful impact on the NCCUSL. The 1992 draft of RUPA was changed to read as it does today, reinserting the phrase "and fair dealing"39 and including fiduciary duties within the list of mandatory duties in section $103 .{ }^{40}$ The comments to section 103 describe the decision to make fiduciary duties mandatory as based on a concern for "unequal bargaining power, information, or sophistication." "41

This brief history may help to explain why RUPA sometimes seems to pull in opposite directions. In some provisions, it appears to endorse reliability and certainty of agreements, even at the cost of a controversial treatment of fiduciary duties. ${ }^{42}$ In others, it endorses nonwaivability of fiduciary duties and

37. Id. at 7.

38. Letter from Melvin A. Eisenberg to the NCCUSL 7 (July 17, 1992). The following quotation from the July 17 letter develops the above arguments:

Persons who enter into a relationship of trust and confidence, in which a contractual override of fiduciary duties originally seems acceptable, may later find that one of their numbers has abused that trust and confidence in a manner that was not and probably could not have been anticipated. More generally, it is almost impossible for contracting parties to adequately assess the future costs and. benefits in a fluid long-term relationship, because events will branch far beyond the ideas of the future that will be conceived when a contract is made. Partnerships by their nature involve a form of activity in which uncertainty plays an essential role. ... [A]n opportunistic partner could often find ways to exploit a contractual provision that eliminated a fiduciary duty even though the provision seemed fair at the time of the contract. It is almost impossible to deal adequately with this potential for ex post opportunism by ex ante Id. at 3-4. contracting.

39. RUPA $\S 404$ (e) (Draft Approved and Recommended for Enactment in All the States 1992).

40. RUPA § 103(b)(3)-(4) (1992).

41. See RUPA $\S 103 \mathrm{cmt}$. 4,6 U.L.A. at 289 (Supp. 1995). It seems odd that those drafting RUPA framed the justification for mandatory provisions in terms of "unequal bargaining power, information, or sophistication" and yet excluded the operation of fiduciary duties at the formation stage of a partnership, where those same concerns would seem to exist, and where the parties ordinarily would be bargaining under an implied understanding of trust and confidence. Id. $\S 404(\mathrm{~b}), 6$ U.L.A. at 313 . Cf. UPA $\$ 21(1), 6$ U.L.A. at 258 (imposing fiduciary duties at the formation stage).

42. See supra text accompanying notes 10-13. 
a broad, undefined mandatory duty of good faith and fair dealing, sacrificing certainty of agreement. ${ }^{43}$

\section{Freedom of Contract: A Pragmatic Perspective}

\section{A. The Bargain Principle}

The bargain principle is a core value of contract law. ${ }^{44}$ It recognizes that entering into a contract is a serious matter and that a contract between parties is to be respected and enforced by the courts, subject to widely accepted limitations that subvert the bargaining process, such as fraud and duress. ${ }^{45}$ Mandatory provisions are inconsistent with the bargain principle. ${ }^{46}$ Recognition of the bargain principle furthers the goal of reliability of agreements.

\section{B. The Nature of a Partnership}

The drafters of RUPA showed considerable respect for the bargain principle. ${ }^{47}$ Considering this, why did they classify fiduciary duties as mandatory, and was that decision wise? To answer these questions is to define the nature of the partnership relationship. Is a partnership relationship simply a contract (of considerable fluidity and complexity) between the co-owners of a business $?^{48}$ If so, fiduciary duties are implied terms of the contract, based logically on the expectations most people would share upon entering such a

43. See supra text accompanying note 25 .

44. See Melvin A. Eisenberg, The Bargain Principle and its Limits, 95 HARV. L. REV. 741, 742 (1982):

By the bargain principle I mean the common law rule that in the absence of a traditional defense relating to the quality of consent (such as duress, incapacity, misrepresentation, or mutual mistake), the courts will enforce a bargain according to its terms, with the object of putting a bargain-promisee in as good a position as if the bargain had been performed.

Id. (note omitted).

45. Id

46. Statutes and administrative regulations have long mandated terms in certain industries, such as the insurance business. See, e.g., Colo. ReV. STAT. \& 10-7-503 (1994) (containing a list of compulsory contract provisions for annuity contracts). These sources of law are independent of the common law bargain principle, however. It is true that RUPA is a uniform act and a legislature enacting it can interfere with partnership contracts in whatever way it chooses. But the law of partnership traditionally has not been viewed as essentially regulatory in nature. Instead, uniform partnership legislation is designed primarily to define standard terms for the many partnerships that do not have formal agreements and to define rights of third parties dealing with partnerships, such as the rights of creditors of a partner (the charging order in UPA $\$ 28,6$ U.L.A. at 358, and in RUPA $\$ 504,6$ U.L.A. at 321 (Supp. 1995)), and the process for giving notice to a partnership (UPA $\$ 12,6$ U.L.A. at 160; RUPA $\S 102,6$ U.L.A. at 287 (Supp. 1995)).

47. See supra notes $11-13$ and 22 (containing language of the reporters for RUPA that is consistent with the bargain principle).

48. Of course, not all co-owners of a business are partners. This article does not address the fiduciary relationship of co-owners of limited liability companies, corporations, and other businesses that, unlike general partnerships, register with the state as a condition of their existence. 
relationship. ${ }^{49}$ The implied terms would be subject to waiver or modification by express terms defining the relationship as the partners wish. ${ }^{50}$ Under this view of partnership, the decision to classify fiduciary duties as mandatory was a mistake.

Or is the partnership relationship something more than a contract, involving inherent fiduciary duties that constitute a mandatory core of the relationship that cannot be bargained away no matter how equal the position of the partners? ${ }^{51}$ In some respects, this approach comes close to a natural law perspective. ${ }^{52}$ It is inconsistent with the bargain principle.

The partnership relationship is most understandably viewed as a contractual relationship in all of its respects, as developed below. This doubtless reflects the view of those who enter partnerships, that they can agree among themselves what they want their relationship to be. From this perspective, it is inappropriate for the state to interfere with a bargain freely and openly made by persons seeking to define a business relationship.

\section{An Argument for Eliminating Sections 103(b)(2)-(4) of RUPA The restrictions on waivability in sections $103(\mathrm{~b})(2)-(4)^{53}$ of RUPA should}

49. See BROMBERG \& RIBSTEIN, supra note $14, \$ 6.07$, at 6:68 ("Fiduciary duties are essentially part of the standard form contract that governs partnerships in the absence of contrary agreement." (cross reference omitted)); see also Jordan v. Duff \& Phelps, Inc., 815 F.2d 429, 436 (7th Cir. 1987) ("Because the fiduciary duty is a standby or off-the-rack guess about what parties would agree to if they dickered about the subject explicitly, parties may contract with greater specificity for other arrangements."), cert. dismissed, 485 U.S. 901 (1988).

50. Weidner states:

A related series of questions concerns the extent to which the fiduciary duties of managing or other partners can be drafted away. If the basic purpose of the fiduciary duties is to protect the presumed legitimate expectations of the parties, the parties should have great latitude to define those expectations by agreement.

Donald J. Weidner, A Perspective to Reconsider Partnership Law, 16 FLA. ST. U. L. REV. 1, 24 (1988); see also Corenswet, Inc. v. Amana Refrigeration, Inc., 594 F.2d 129 (5th Cir.) (a well-known case clearly holding that an implied term of good faith is overridden by an express term of the contract), cert. denied, 444 U.S. 938 (1979).

51. See infra text accompanying notes 73-84 (developing the view that the partnership relationship carries with it inherent fiduciary duties).

52. That is, the inherent fiduciary duties argument seems to rest on a moral sense that overrides the bargain principle without regard to the circumstances of the bargain and without application of the customary limitations on the bargain principle. For a discussion of natural law, see GEORGE C. CHRISTIE \& PATRICK H. MARTIN, JURISPRUDENCE : TEXT AND READINGS ON THE PHILOSOPHY OF LAW 125 (2d ed. 1995) ("With respect to the basic epistemological question of how do we come to know the natural law, ... [some natural lawyers] have laid considerably more stress on our natural human instincts, on a natural moral sense implanted in human beings.").

53. See supra note 7. Subsection (2) prohibits unreasonable restrictions on the right of access to books and records under $\$ 403(\mathrm{~b})$. Subsection (3) restricts agreements concerning the duty of loyalty. Subsection (4) prohibits "unreasonable" reductions of the duty of care. With regard to subsection (2), not previously addressed in this essay, RUPA $\$ 403(b)$ states that a partnership "shall provide" partners access to its books and records. Section 103(b)(2) states that the right in $\S 403$ (b) cannot be restricted "unreasonably" by agreement. It is not clear why the invitation to judicial scrutiny of the partnership agreement is broader (because a partner need only prove that a restriction is unreasonable, not manifestly unreasonable) for contract terms altering the duties in subsections (2) and (4) than it is for 
be deleted because they interfere with the right of partners to define their relationship as they wish. ${ }^{54}$ Persons entering into a partnership relationship ordinarily bargain from an approximately equal position, an equality created by the fact that each party typically has something of near-equal value to offer the other. That is the reason partnership status is being offered by one party and sought by the other. This should give presumptive validity to the bargain of the parties. ${ }^{55}$ Thus, for example, if two large corporations decide to enter into a joint venture for a long-term project,,$^{56}$ they ought to be free to forego fiduciary duties in order to avoid the risk of future litigation over vague and fact-specific concepts. They do not trust each other and never will trust each other to keep the other party's interests in mind. Honesty in response to specific questions is all either party expects. ${ }^{57}$ The law should respect that bargain. Thus, it can be argued that RUPA section 103 is overly intrusive. It intervenes in an

contract terms altering the duties in subsection (3). It is also unclear why the other duties in $\S 403$, that each partner and the partnership furnish to a partner information concerning the partnership business and affairs, are not subject to any $\S 103$ restrictions on contrary agreement. The comment to $\S 103$ on these provisions states:

Subsection (b)(2) provides that the partnership agreement may not unreasonably restrict a partner or former partner's access rights to books and records under Section 403(b). It is left to the courts to determine what restrictions are reasonable. Other information rights in Section 403 are subject to contrary agreement.

RUPA \& $103 \mathrm{cmt} ., 6$ U.L.A. at 289 (Supp. 1995)

The arguments made in the above text with regard to the bargain principle apply to the restriction contained in $\S 103(\mathrm{~b})(2)$. One can imagine partners not wanting to be second-guessed about the restrictions they place on full access to books and records, particularly under circumstances where they are attempting to cope with demands made by a difficult partner.

With regard to the questions raised in the first paragraph of this note, there are three different standards that can be used in $\S 103$ : unreasonable, manifestly unreasonable, and unconscionable. The challenge is to select the standard that will most carefully fit the competing interests involved. See infra text accompanying notes 108-26 (developing this topic).

54. See Frank H. Easterbrook \& Daniel R. Fischel, Contract and Fiduciary Duty, 36 J. L. \& ECON. 425,429 (1993) ("To say that express contracting is allowed is to say that the law is designed to promote the parties' own perception of their joint welfare.").

55. For a case manifesting a strong tendency to uphold agreements among partners, see $\mathrm{G} \& \mathrm{~S}$ Invs. v. Belman, 700 P.2d 1358, 1367-68 (Ariz. Ct. App. 1984):

Partnership buy-out agreements are valid and binding although the purchase price agreed upon is less or more than the actual value of the interest at the time of death.

Buy-out agreements are enforceable even when they provide that the decedent's interest shall pass to the survivors without any payment. . . .

We do not have the power to rewrite [the agreement] based upon subjective notions of fairness arising long after the agreement was made or because the agreement did not turn out to be an advantageous one. Modern business practice mandates that the parties be bound by the contract they enter into, absent fraud or duress. It is not the province of the court to act as the post-transaction guardian for either party. (citations omitted).

56. Joint ventures are treated as partnerships when resolving legal matters. E.g., Groff v. Citizens Bank of Clovis, 898 F.2d 1475, 1476-77 (10th Cir. 1990).

57. See infra part II.F for an argument that the mandatory duty of good faith should be interpreted to mean honesty in fact. Indeed, it is hard to imagine any definition of good faith not containing at minimum a requirement of honesty. Also, it is hard to imagine any partnership agreement disclaiming honesty among partners, even were that permitted. 
essentially private relationship among persons of presumptively equal bargaining power. ${ }^{58}$

\title{
D. The Singer and Riviera Cases
}

The issue of defining limits on the power to vary fiduciary duties by contract is not new. RUPA arguably would change existing law in some jurisdictions. Case authority exists under the UPA that recognizes the primacy of the partnership agreement, even when substantial inroads into fiduciary duties are at issue. The case of Singer $v$. Singer ${ }^{59}$ is a dramatic example of this. The partnership agreement in Singer stated in relevant part:

\begin{abstract}
Each partner shall be free to enter into business and other transactions for his or her own separate individual account, even though such business or other transaction may be in conflict with and/or competition with the business of the partnership. Neither the partnership nor any individual member of this partnership shall be entitled to claim or receive any part of or interest in such transactions, it being the intention and agreement that any partner will be free to deal on his or her own account to the same extent and with the same force and effect as if he or she were not and never had been members of this partnership. ${ }^{60}$
\end{abstract}

The partnership (Josaline) was in the oil production business. Prior to a meeting of the partners, one partner requested another (Stanley) to look into the possibility of purchasing a particular parcel of land containing minerals. At the meeting, the land was briefly discussed but further action was deferred. After the meeting, Stanley and another partner formed a separate partnership and bought the land for themselves. ${ }^{61}$ When these facts were discovered, Josaline brought an action to have the land held in constructive trust. ${ }^{62}$ The trial court's decision in favor of plaintiff was reversed on appeal. The appellate court stated:

We find that the defendants had a contract right to do precisely what they did, namely, compete with the partners of Josaline and with Josaline itself "as if there had never

58. Professor Ribstein has written a number of essays on this issue. In one of his most recent statements, directly related to this topic, he states:

Mandatory fiduciary duties change decades of prior law under the UPA. . . Mandatory fiduciary duties also are bad policy because they preclude worthwhile contracts. For example, RUPA prevents partners from (i) contracting out of a duty of care where the probability that a partner with a heavy investment in the firm and exposure to personal liability will be grossly negligent is so low as not to be worth the costs and risks of litigation... [or] (iii) letting a managing partner enter into contracts with the partnership on behalf of the partner's management company. . . There is no good reason for flatly prohibiting all of these contracts.

Larry E. Ribstein, The Revised Uniform Partnership Act: Not Ready for Prime Time, 49 Bus. LAw. 45, 57-58 (1993) (notes omitted); see also Henry N. Butler \& Larry E. Ribstein, Opting out of Fiduciary Duties: A Response to the Anti-Contractarians, 65 WASH. L. REV. 1, 29 (1990) ("In selecting between fiduciary duties and alternative constraints, the parties consider both the costs and benefits of fiduciary duties, and at the margin trade off fiduciary duties for other constraints. ... [T] [Te parties ... may conclude that the costs of fiduciary duties outweigh their gap-filling benefits.").

59. 634 P.2d 766 (Okla. Ct. App. 1981).

60. Id. at 768 (emphasis removed).

61. Id. at 769 .

62. Id. at 767 . 
been a partnership" ... . Josaline contracted away its right to expect a noncompetitive fiduciary relationship with any of its partners.

We find paragraph 8 is designed to allow and is uniquely drafted to promote spirited, if not outright predatory competition between the partners. ${ }^{63}$

Singer does not stand alone in its deference to the partnership agreement. Riviera Congress Associates v. Yassky ${ }^{64}$ involved a claim by limited partners in a real estate syndicate against the general partners of the syndicate, who were sued in their capacities both as general partners and as holders of the leasehold interest in the large motel owned by the partnership. The claim was based on self-dealing. The New York Court of Appeals stated:

The plaintiffs charge a breach of fiduciary duty by the general partners in that they were assertedly guilty of self-dealing and, on the surface, it is difficult to dispute the fact of such self-dealing since they leased the motel to their own thinly capitalized corporation and then consented to successive assignments of the lease to other business entities which they owned or controlled. Ordinarily, such self-dealing would render the defendants incapable, as general partners, ... from releasing themselves from liability on the lease .... However, partners may include in the partnership articles practically "any agreement they wish" and, if the asserted self-dealing was actually contemplated and authorized, it would not, ipso facto, be impermissible and deemed wrongful. As bearing on this, it seems clear that the limited partners were fully apprised in the prospectus that the defendant general partners intended to lease the premises to their own corporation [which was thinly capitalized]. This clear statement of purpose has the effect of "exonerating" the defendants, at least in part, "from adverse inferences that might otherwise be drawn against them" simply from the fact that they dealt with themselves. Since the papers before us disclose an issue whether the defendants acted "honestly and in good faith," determination of that question may only be resolved upon a trial. ${ }^{65}$

It is doubtful whether Singer or Riviera would survive the adoption of RUPA. In Singer, the duty of loyalty was in effect abrogated by the partnership agreement. This would seem to call into play section 103(b)(3), which forbids eliminating the duty of loyalty. ${ }^{66}$ Even if the provision in Singer were not found to eliminate altogether the duty of loyalty, one can easily imagine a court characterizing the language in the partnership agreement as manifestly unreasonable. ${ }^{67}$

Riviera involved the distinct situation of a suit by limited partners against their general partners. Unlike general partners, limited partners ordinarily do not exercise control in the business ${ }^{68}$ and are unable to protect themselves

63. Id. at 772 .

64. 223 N.E.2d 876 (N.Y. 1966).

65. Id. at 880 (citations omitted).

66. See supra note 7 for the text of RUPA $\$ 103,6$ U.L.A. at 288-89 (Supp. 1995).

67. Id. (quoting $\S 103(\mathrm{~b})(3)(\mathrm{i})$, which forbids manifestly unreasonable provisions in the partnership agreement that identify activities that do not violate the duty of loyalty).

68. A limited partner who exercises control "substantially the same as a general partner" is liable for the debts of the business. REVISED UNIF. LTD. PARTNERSHIP ACT $\S 303$ (last amended 1985), 6 U.L.A. 505 (Supp. 1995) (1976 text, prior to 1985 amendments). Even after the 1985 amendments, which cut back sharply on this liability, RULPA contains some residual risk for an active limited partner. Id. 
from a deteriorating situation by withdrawing from the partnership. ${ }^{69}$ This would seem to intensify a court's scrutiny of contract provisions that make inroads into fiduciary duties that general partners owe limited partners. ${ }^{70}$ One can imagine a court operating under RUPA ${ }^{71}$ deciding that a provision such as the one involved in Riviera is manifestly unreasonable, on the theory that it imposes an unfair risk on the limited partners and operates too much to the advantage of the general partners.

Regardless of one's views of the quality of the behavior of the defendant partners in Singer and Riviera, those courts saw a strong interest in upholding the agreement into which the plaintiffs voluntarily entered. Adopting RUPA would make an inroad into the bargaining principle established by those courts. $^{72}$

\section{E. Arguments in Favor of Mandatory Duties}

The arguments made above are far from undisputed. One argument that can be made in favor of the RUPA restrictions is that the mutual agency among partners sets the relationship apart from a normal contractual arrangement and defines it in a way that can never tolerate treating it as an arm's length transaction. ${ }^{73}$ Mutual agency creates a relationship of trust and confidence among partners because agency involves acting on behalf of others and being entrusted with certain powers. ${ }^{74}$ A partner, as general agent, is entrusted with powers to commit fellow partners to courses of action that sometimes involve the risk of major liability and the commitment of substantial resources. It can be argued that one can never sensibly bargain away the protections of loyalty and care that fiduciary duties provide in such circumstances. This argument is undermined, however, by the fact that the law of agency takes a strong position

69. Compare RULPA $\S 801$ (4), 6 U.L.A. at 569 (allowing only general partners to withdraw at will) with RUPA $\$ 602(a), 6$ U.L.A. at 325 ("A partner has the power to dissociate at any time, rightfully or wrongfully, by express will pursuant to Section 601(1)."). RUPA introduces the concept of dissociation, which in many instances displaces dissolution under the UPA. RUPA § 601, 6 U.L.A. at 325-26 (Supp. 1995). Whether one calls it dissociation or dissolution, however, a general partner under RUPA can leave the business at any time by act of will. Dissociation does not provide a perfect solution to a deteriorating situation because losses may have already been incurred prior to exercise of the right to dissociate. Nevertheless, it provides an option to general partners that is not available to limited partners. And the threat to exercise that option sometimes can lead to productive negotiation among the involved parties.

70. See supra text accompanying note 37 (noting that Professor Eisenberg draws a distinction between general and limited partnerships with respect to the freedom to contract around fiduciary duties).

71. This assumes that RUPA is linked to limited partnership legislation in a state that enacts it, making the provisions of RUPA applicable to general partners operating in a limited partnership.

72. Of course, cases exist that hold differently, refusing to recognize provisions in a partnership agreement that make substantial inroads into fiduciary duties. E.g., Appletree Square I Ltd. Partnership v. Investmark, Inc., 494 N.W.2d 889 (Minn. Ct. App. 1993).

73. See RUPA $\S 301,6$ U.L.A. at 299 (Supp. 1995) (declaring partners agents of their partnership).

74. See ReSTATEMENT (SECOND) OF AGENCY \& 1 (1958). 
in favor of freedom of contract between principal and agent. ${ }^{75}$ Thus, the existence of an agency relationship cannot in itself be the explanation for mandatory fiduciary duties.

A second argument in favor of the RUPA restrictions is based on Professor Eisenberg's contention that partners are unable accurately to foresee what abuses can be committed by an opportunistic partner. ${ }^{76}$ A foreseeability argument cuts both ways, however. That is, a lack of foreseeability is what drives partners to draft provisions qualifying or eliminating fiduciary duties. Foreseeability in this context relates not to opportunistic behavior but rather to what courts may do in interpreting and applying mandatory fiduciary duties. ${ }^{77}$ Also, while Professor Eisenberg's concern about the danger of an opportunistic partner exploiting a contractual provision that eliminates a fiduciary duty is unquestionably valid, disappointed partners (as contrasted with corporate shareholders ${ }^{78}$ or limited partners) have options available to them which militate against this danger, including rights of control or, if those also have been bargained away, dissociation or dissolution powers. ${ }^{79}$ If the situation has become intolerable, a disappointed partner can leave the partnership. ${ }^{80}$

A third argument in favor of mandatory fiduciary duties is that they "supply standardized content for the legal consequences of [partnership] relationships," and thus reduce the need for highly particularized investigations into, for

75. A principal and an agent are free to tailor their relationship as they wish. This includes consent by a principal to a direct conflict of interest by the agent in the transaction at issue. RESTATEMENT (SECOND) OF AGENCY $\$ 391$ (1958) ("Unless otherwise agreed, an agent is subject to a duty to his principal not to act on behalf of an adverse party in a transaction connected with his agency without the principal's knowledge."). The phrase "unless otherwise agreed" qualifies many other fiduciary duties in the RESTATEMENT (SECOND) OF AGENCY. E.g., id. $\$ \$ 379$ (duty of care), 380 (duty of good conduct), 381 (duty to give information), 388 (duty to account for profits), and 395 (duty not to use confidential information).

76. See supra text quoted in note 37.

77. See Ribstein, supra note 58 , at 59 ("But the partners' inability to foresee the future does not explain why they should be forced to permit future legal challenges, no matter how unpredictably harmful to the firm these challenges may be.").

78. Even with regard to corporate shareholders, authority exists that recognizes an implied waiver of fiduciary duties under some circumstances. See Coleman v. Taub, 638 F.2d 628 (3d Cir. 1981), where the court held that a minority shareholder had bargained away the fiduciary duty owed him by the majority shareholder under Delaware law by signing an employment contract containing a buy-back clause:

[A] minority shareholder may bargain away the "additional interest" in corporate participation

which might otherwise be the basis for a fiduciary duty on the part of the majority. ...

[T] here is no reason why an appeal to general fiduciary law should be used by either party as a pretext for evading his contractual obligations. Id. at 636.

79. See RUPA $\$ \$ 601,801,6$ U.L.A. at 322, 335 (Supp. 1995).

80. Any partner has the right to seek court dissolution when "it is not . . reasonably practicable to carry on the partnership business in conformity with the partnership agreement." Id. $\$ 801$ (5)(iii), 6 U.L.A. at 335 . This broad language would seem to fit the circumstance of abuse by an opportunistic partner quite well. It is not a perfect solution, as the opportunistic partner will usually have already caused some harm. What is involved is a trade off: greater freedom of contract and certainty versus the risk that an opportunistic partner will take advantage of other partners by abusing the agreement between them prior to dissolution of the partnership. 
example, the character of the person in whom one will be placing trust. ${ }^{81}$ Such benefits are compelling. ${ }^{82}$ However, those same benefits are available in a default setting. That is, because default rules apply unless specifically contracted away, they also supply standardized content for a partnership relationship. Furthermore, default fiduciary rules reduce the need for a particularized investigation into character prior to entering into a relationship equally as effectively as mandatory rules. The very suggestion by the fiduciary that the customary protections be drafted away would serve as a warning that something is wrong. At that point, an investigation into character indeed would be triggered, but under such circumstances it would be cost effective because it would redound to the benefit of the party who is about to place trust in someone who has sent a signal that all may not be well.

A final argument in favor of mandatory fiduciary duties is made by Professor Vestal: "The contractarian formulation jeopardizes unsophisticated participants, inadvertent partners, partners with insufficient resources to retain counsel and enter into lengthy negotiations, and individuals with inadequate experience to appreciate the problem." ${ }^{83}$ These words are forceful and troubling. There is no doubt that a move toward greater freedom of contract comes at a cost, and Professor Vestal has identified some of the potential victims. No one wants to see sharp and hard operators take advantage of the vulnerable and the unsophisticated.

Protecting those who are unsophisticated and inexperienced through mandatory duties also comes at a cost, however: that imposed by the uncertainty created by the risk of aggressive judicial intrusion into private bargaining. This cost weighs more heavily in the partnership setting, where the incentive to take advantage of unsophisticated and vulnerable people ordinarily would be at a minimum because of the nature of the relationship being established. One can assume that few people are anxious to become partners of a naive, unsophisticated, inexperienced person who would, by becoming their partner, also become their general agent and co-owner of their business. The nature of the relationship thus does not seem ripe for exploitation in the ordinary case, weakening the need for mandatory duties. In the extraordinary case, relief is available under the doctrine of unconscionability. This doctrine operates as a

81. Deborah A. DeMott, Fiduciary Obligation Under Intellectual Siege: Contemporary Challenges to the Duty to be Loyal, 30 OSGOODE HALL L.J. 471, 491 (1992).

82. See also Claire Moore Dickerson, Is It Appropriate to Appropriate Corporate Concepts: Fiduciary Duties and the Revised Uniform Partnership Act, 64 U. CoLO. L. REV. 111, 155-56 (1993) ("Once the partnership form has been chosen, there would be no purpose in wasting time-and transaction costs-on negotiating the terms of a fiduciary duty. I do not agree with contractarian commentators who maintain that the traditional fiduciary duties are so vague and aspirational as to be meaningless. ... Far from being naively aspirational, those duties serve to guide the parties to a standard of behavior that reduces the need to monitor." (note omitted)).

83. Vestal, supra note 5, at 541. Professor Vestal further states: "From a social perspective, both the opportunity for exploitation and the debasement of the partnership concept are disturbing." Id. at 562. 
sufficient protection for truly compelling cases and is less intrusive than mandatory duties because, as developed below, it is situation-specific. ${ }^{84}$

Many of the above arguments in favor of mandatory fiduciary duties are appealing. A decision on one side or the other is far from simple. On balance, however, it seems better to treat fiduciary duties as default rules. The customary contract defenses of undue influence, duress and fraud are available to partners whose consent has been unfairly obtained. In addition, the doctrine of unconscionability should play a major role in policing agreements where one partner clearly takes unfair advantage of another. This is sufficient protection. The interest in freedom of contract, so confined, outweighs any interest gained through mandatory terms, which operate indiscriminately to destroy inoffensive as well as offensive agreements.

If one is concerned about giving away too much fiduciary protection when entering into a partnership with a virtual stranger, one can simply refuse to sign an agreement eliminating those duties. At some point it seems appropriate for courts to call on people to protect their own interests and to take personal responsibility for their agreements. That point is reached when judicial intrusion imposes too great a cost, in terms of unreliability of contracts, in return for too little benefit to the great majority of those who enter into partnership agreements.

\section{F. The Separate Matter of Good Faith and Fair Dealing}

The above discussion has dealt with waivers of fiduciary duties. The duty of good faith and fair dealing also is not waivable under RUPA ${ }^{85}$ Although excluded from the definition of fiduciary duties, ${ }^{86}$ if broadly defined it can present equal problems of uncertainty for partners.

The duty of good faith and fair dealing, read broadly, is vague and openended. ${ }^{87}$ This made it a natural candidate for exclusion from the definition of fiduciary duties under the approach of those drafting RUPA, who sought to limit the vagueness created by broad and open fiduciary duties. It is a matter of some irony, therefore, that the duty of good faith and fair dealing, although mandatory, is not defined in RUPA. ${ }^{88}$ Those drafting RUPA chose to leave its definition to gradual development by judicial decision. ${ }^{89}$

84. See infra text accompanying notes $116-27$.

85. RUPA § 103(b)(5), 6 U.L.A. at 289 (Supp. 1995); see supra note 7.

86. See supra text accompanying note 14.

87. See generally Robert S. Summers," "Good Faith" in General Contract Law and the Sales Provisions of the Uniform Commercial Code, 54 VA. L. REV. 195 (1968).

88. The comment to $\S 404$ states:

The meaning of "good faith and fair dealing" is not firmly fixed under present law. Good faith clearly suggests a subjective element, while fair dealing implies an objective component. It was decided to leave the term undefined in the Act and allow the courts to develop its meaning based on the experience of real cases.

RUPA $\S 404$ cmt. 4, 6 U.L.A. at 315, (Supp. 1995).

89. Id. 
The decision to leave the duty of good faith and fair dealing undefined, though understandable as an abstract matter considering the generality of the concept, introduces substantial vagueness and uncertainty into the law of partnership. When coupled with the classification of the duty as mandatory, it leaves the reader wondering just how much has been accomplished by the controversial treatment of fiduciary duties in RUPA. Courts seem to be as free to read their values into an undefined mandatory duty of good faith as they would have been with an open and nonexclusive definition of fiduciary duties.

To minimize the danger of uncertainty, "good faith" is best defined as it is in Article 1 of the Uniform Commercial Code, as "honesty in fact in the conduct or transaction concerned." 90 The advantage of this definition is that it is narrow and fairly specific. ${ }^{91}$ A standard of honesty is less vague than one of fairness. ${ }^{92}$ It reduces the risk of litigation over difficult decisions that may involve conflicting interests. ${ }^{93}$

90. U.C.C. § 1-201(19) (Supp. 1994); see also MODEL EMPLOYMENT TERMINATION ACT §1(7), 7 A U.L.A. 75 (Supp. 1995) (good faith defined as "honesty in fact"). The Act sets a good cause standard for discharge of employees, defining good cause as including "the exercise of business judgment in good faith by the employer." Id. It is significant that good faith is defined as honesty in fact in the context of setting standards for employment relationships, where the assumption that the parties bargain from an equal position normally is not made. This provides support for defining good faith as honesty in fact in a partnership relationship, which ordinarily is a relationship of far greater equality than that of employment.

91. The argument that the law of deceit (fraud) already addresses this interest (and thus an "honesty in fact" standard accomplishes nothing) is not convincing. The tort of fraud includes other elements besides dishonesty, such as a requirement of reliance. See Desert Equities, Inc. v. Morgan Stanley Leveraged Equity Fund II, L.P., 624 A.2d 1199, 1208 (Del. Super. Ct. 1993). In many states, fraud also carries a higher burden of proof. See, e.g., E. AlLAN FARNSWORTH, CONTRACTS 491 (2d ed. 1990) (noting that courts have often said that fraud must be proved "by clear and convincing evidence" in a suit for reformation).

92. Litigation over the "honesty in fact" standard demonstrates that it can be usefully applied in many situations. Watseka First Nat'l Bank v. Ruda, 552 N.E.2d 775 (Ill. 1990), a nonpartnership case, contains a thoughtful opinion addressing both narrow (honesty in fact) and broad (act in a commercially reasonable manner) definitions of good faith. The court was dealing with the acceleration by a bank of a note, based on an insecurity clause. U.C.C. \$ 1-208 was read to mandate an "honesty in fact" standard for the bank's action. The court gave several illustrations where the plaintiff debtor could prove a case of bad faith despite facing a subjective standard. The court also stated:

[w]e must conclude that the drafters [left out the obligation to act in a commercially reasonable manner] purposely, finding perhaps that inclusion of the "commercially reasonable" standard for acceleration would detrimentally affect the cost and availability of credit, and that this outweighed any potential for abuse that the provision posed.

Watseka, 552 N.E.2d at 779.

93. See supra note 5 for reference to RUPA $\$ 404(\mathrm{e})$, addressing the conflicting position of a partner, who is both a fiduciary and a co-owner seeking personal profit from the business. This candid acknowledgement of the unique position of a partner, and the recognition in subsection (e) that a partner's conduct can further his own interest, supports the proposition that the Act should narrow the exposure of partners operating under such circumstances to litigation on good faith grounds. Defining good faith as "honesty in fact" would be one step toward that goal. Of course, one could argue the opposite, that the possibility of conflicting interests enhances the need for a broad duty of good faith. 
If the partners want a broader standard for the duty of good faith, they can bargain for it. ${ }^{94}$ The "honesty in fact" standard operates only as a minimum. This allocation of the burden of drafting seems appropriate not only for reasons of certainty but also because there exists for many people in business an intangible incentive to avoid sharp dealing, that of concern for personal reputation. Partners are in business together, in a relationship of some complexity and ordinarily of indefinite duration. Most people are concerned about maintaining their reputation for fair dealing under such circumstances, if for no other reason than the desire to preserve future opportunities. This incentive does not deter everyone, of course, or we would have no cases involving sharp dealing and abuse of trust. But it deters enough people that it seems appropriate to put the burden of drafting on those who seek more than a mandatory standard of honesty in fact.

An argument against a definition of good faith as "honesty in fact" is that it is too narrow, particularly in view of the addition of the phrase "and fair dealing" to the duty of good faith..$^{95}$ A standard of honesty can be abused by a party who violates the spirit of the partnership contract. ${ }^{96}$ A sharp operator who has no appreciation for a relationship of trust can cause considerable damage to other partners without lying to them. Also, the argument that partners can bargain for a broader standard, while true, does not take into account the many inadvertent or casual partnerships that are created without even considering the issue.

For a non-partnership case articulating an economic rationale for a broader reading of good faith, see Market Street Associates Ltd. Partnership v. Frey. ${ }^{97}$ In Frey, one party to a contract, who was claiming a right under the contract to buy certain property in which both parties had an interest, failed to call to the attention of the other party a specific term in the contract relating to the right to buy which operated to the disadvantage of the other party. In the course of his opinion recognizing the merits, under some circumstances, of a claim of bad faith for the failure to call attention to the term, Judge Posner stated:

It is another thing to say that you can take deliberate advantage of an oversight by your contract partner concerning his rights under the contract. Such taking advantage is . . . sharp dealing. Like theft, it has no social product, and also like theft it induces costly defensive expenditures, in the form of overelaborate disclaimers or investigations into the trustworthiness of a prospective contract partner .... The concept of the duty of good faith like the concept of fiduciary duty is a stab at approximating the terms the parties would have negotiated had they foreseen the circumstances that have given rise to their dispute. The parties want to minimize the costs of performance.

94. The author has no quarrel with a broad definition, or no definition, of a default rule of good faith, which would reverse the burden of drafting from that proposed here. But the drafters of RUPA chose not to take that route.

95. See supra note 4 (quoting RUPA \$ 404(d), 6 U.L.A. at 313); see also Robert M. Phillips, Good Faith and Fair Dealing Under the Revised Uniform Partnership Act, 64 U. COLO. L. REV. 1179 (1993) (examining both phrases and defining them in a way that differs from the author's definition).

96. See Ribstein, supra note 58, at 55.

97. 941 F.2d 588 (7th Cir. 1991). 
To the extent that a doctrine of good faith designed to do this by reducing defensive expenditures is a reasonable measure to this end, interpolating it into the contract advances the parties' joint goal. ${ }^{98}$

The goal of reducing defensive expenditures is a worthy one. The court's use of a broad good faith standard to achieve this goal reached a paradoxical result in the case before it, however, leading to the question whether an "honesty in fact" standard might not have been more appropriate. The result of Frey is paradoxical because it could increase, not reduce, expenditures by reducing the incentive for parties to acquire familiarity with their own contracts. This creates uncertainty and may increase costs because it makes contracting parties vulnerable to charges of breach by bad faith if they fail to remind the other party of specific provisions of their joint contract. This results in an unfair advantage to the other party, which is able successfully to plead ignorance of its own contract.

The issue of the proper definition of good faith is difficult and troubling, with appealing arguments on both sides. Much can be said for requiring a broad standard of good faith among partners, considering the complex, longterm relationship of trust and confidence involved in the usual partnership. And there is a strong argument that good faith should approximate what the partners would have agreed to had they addressed the issue. But the issue being addressed is a mandatory duty of good faith. A broad default rule is one thing, a mandatory rule quite another. Also, a broad doctrine of good faith is a twoedged sword: it can be used as a weapon by a disappointed partner to exploit ambiguity and complexity and generate a dispute, perhaps forcing an unjust settlement. On balance, it seems preferable to require only the minimum standard of honesty, and leave the parties free to bargain for higher duties if it suits their situation.

\section{G. A Look at Delaware}

The state of Delaware recently amended its limited partnership act in a way that attracted considerable attention in the legal world. ${ }^{99}$ The amendment added the following provision:

To the extent that, at law or in equity, a partner has duties (including fiduciary duties) and liabilities relating thereto to a limited partnership or to another partner, (1) any such partner acting under a partnership agreement shall not be liable to the limited partnership or to any such other partner for the partner's good faith reliance on the provisions of such partnership agreement, and (2) the partner's duties and liabilities may be expanded or restricted by provisions in a partnership agreement. ${ }^{100}$

98. Id. at 594-99. It is important to keep in mind that Judge Posner is addressing a default good faith standard, operating under circumstances in which the parties have not negotiated on the subject

99. See generally Larry E. Ribstein, Unlimited Contracting in the Delaware Limited Partnership and Its Implications for Corporate Law, 16 J. CORP. L. 299 (1991).

100. 67 Del. Laws 757, 757-58 (1990), codified as amended at DEL. CODE ANN. tit. 6, § 17-1101(d) (Supp. 1994). 
This language recognizes the centrality of the partnership agreement and thus is consistent with and advances the arguments made in this article. ${ }^{101}$ It would fit naturally in RUPA section 404 , where the duties of a partner are defined, although the language of section 103 would have to be amended accordingly.

The Delaware language incorporates a standard of good faith. This could be read to reintroduce mandatory fiduciary duties through a broad interpretation of good faith. This argument is compromised, however, by the wording of the statute: "good faith reliance on the provisions of the agreement."102 This narrows the reach of the good faith standard, which is confined to interpreting the parties' contract. ${ }^{103}$ Also, Delaware courts have required "a tortious state of mind" to show a breach of good faith under the statute. ${ }^{104}$ This could be read to incorporate a standard of "honesty in fact," on the reasoning that a tortious state of mind means a fraudulent state of mind. This reading is reinforced by the philosophy of the statutory language, which is to narrow, not expand, liability. ${ }^{105}$

The statutory approach of Delaware is particularly striking because it is in the Delaware limited partnership act. As noted above, limited partners as a class are in a more vulnerable position than general partners. ${ }^{106}$ They ordinarily do not exercise control and do not enjoy dissociation or dissolution powers. This would seem to increase the danger of exploitation and abuse by general partners in a limited partnership. Yet the language introduced by Delaware can be defended. ${ }^{107}$ Certainly, it supports including a similar provision in RUPA, which addresses general partnerships, where the parties to the contract enjoy control and dissociation powers.

\section{IV}

\section{An Alternative: Revising the language of Section 103}

It is the view of the author that deleting the provisions in section 103 that mandate fiduciary duties would be a logical extension of the bargain principle. It is clear, however, that strong views of highly regarded scholars are to the contrary. This makes it prudent to suggest an alternative. Even if one disagrees with deleting altogether the limitations in sections 103(b)(2)-(4), a gesture

101. Note, however, that the language of the Delaware statute uses the word "restricted," not "eliminated." This makes possible an argument that a mandatory core of fiduciary duties remains untouched.

102. DEL. CODE ANN. tit. 6, §17-1101(d)(1) (Supp. 1994) (emphasis added).

103. Ribstein, supra note 99 , at 300 n.4.

104. Desert Equities, Inc. v. Morgan Stanley Leveraged Equity Fund II, L.P., 624 A.2d 1199, 1208 (Del. Super. Ct. 1993).

105. For a thoughtful discussion of Delaware case law on this issue, see Deborah A. DeMott, Fiduciary Preludes: Likely Issues for LLCs, 66 U. CoLO. L. REV. (forthcoming 1995).

106. See supra text accompanying notes 68-71.

107. Not all limited partners are unsophisticated, naive investors. See Ribstein, supra note 58 , at 58 n.102. 
toward the bargain principle nevertheless can be made by changing the wording of section 103.

\section{A. The Drawbacks of "Manifestly Unreasonable"}

The phrase "manifestly unreasonable" is used in subsections (b)(3) (duty of loyalty) and (b)(5) (duty of good faith and fair dealing) to limit the extent to which the partnership agreement can reduce duties. ${ }^{108}$ It was borrowed from the Uniform Commercial Code, which uses it in several places. ${ }^{109}$ The phrase does not have a defined history, ${ }^{110}$ nor has it generated a body of case law that is helpful in giving it content. Warranty limitation cases constitute the bulk of the case law interpreting this phrase, and almost all the decisions are conclusory in tone. ${ }^{111}$

It thus is difficult to get a sense of the meaning behind the phrase "manifestly unreasonable." "12 Apparently the word "manifestly" was used to discourage retroactive declarations of unreasonableness based on how a transaction later turns out. ${ }^{113}$ A court is expected to make a judgment on

108. Supra, note 7. As noted supra note 53, the word "unreasonably" is used in $\S 103(\mathrm{~b})(2)$ and (4), qualifying contractual reductions of the right to books and records and the duty of care. The arguments made in the text with regard to "manifestly unreasonable" would apply with even greater strength to subsections (2) and (4).

109. U.C.C. $\$ \$ 1-102(3),-201(37)(z),-204(1)$ (1989 \& Supp. 1994), 2A-103(1)(u) (Supp. 1994), 4$103(1), 8-402(2)(1991), 9-501(3)(1992)$.

110. The phrase first appears in the March 1,1950, “Text Only" printing of the UCC, at \$1-204, which is in its current form. An article discussing the change introduced by the phrase and the different interpretations given it is contained in Daniel H. Lidman, Time Limitations on Warranties: Application and Validity Under the UCC, 11 B.C. INDUS. \& COM. L. REV. 340, 343-47 (1970).

111. See, e.g., Neville Chemical Co. v. Union Carbide Corp., 422 F.2d 1205 (3d Cir.) (contract term requiring 15-day notice of defect held manifestly unreasonable if interpreted to include latent defects which could not be discovered until after complex chemical reaction took place well after the notice period expired), cert. denied, 400 U.S. 826 (1970); Koch Supplies, Inc. v. Farm Fresh Meats, Inc., 630 F.2d 282 (5th Cir. 1980) (contract term required notice of defect within 48 hours of delivery; smokehouse required several weeks to install, so defect could not be discovered within allotted time; the 48-hour limitation was held manifestly unreasonable).

112. See LAw Revision COMmission STATE OF NEW YORK REPORT OF tHE LAW REVISION COMMISSION FOR 1955, at 315-19 (articles by Professor Carl H. Fulda and Professor Edwin W. Patterson); see also 2 Grant Gilmore, SECURITY INTERESTS IN PERSONAL PROPERTY 1130 (1965), stating:

The bow which $\S 1-102(3)$ makes in the direction of freedom of contract may seem to say that courts are precluded from examining clauses which purport to "determine the standards" of "reasonable care" even if the standards are unreasonable, provided they are not "manifestly" so. It is unlikely that the most convinced advocate of freedom of contract would care to argue that his client's "agreement," although unreasonable, stopped just short of "manifest" unreasonableness and was thus protected against judicial invalidation. "Reasonable care" will continue to be what the judges say it is. (note omitted).

113. See U.C.C. $\$ 1-204$, cmt. 1, which states:

Subsection (1) [containing the "manifestly unreasonable standard"] recognizes that nothing is stronger evidence of a reasonable time than the fixing of such time by a fair agreement between the parties. However, provision is made for disregarding a clause which whether by inadvertence or overreaching fixes a time so unreasonable that it amounts to eliminating all remedy under the contract. The parties are not required to fix the most reasonable time but may fix any time which is not obviously unfair as 
unreasonableness based directly on the agreement itself, with "manifestly" measured by the language and circumstances of the agreement at the time of making. ${ }^{114}$ This invites judicial review without regard to the bargaining posture of the parties. Instead, a court can decide a case based simply on its assessment of the unreasonableness of a term. An added drawback is that there is precedent for sending a case to a jury for a determination of whether a contract provision is manifestly unreasonable. ${ }^{115}$ That undermines an effort to build up a body of articulated law around the phrase.

\section{B. An Argument for Substituting "Unconscionable"}

The word "unconscionable" is a term of art in the Uniform Commercial Code. ${ }^{116}$ It has a history ${ }^{117}$ and has developed a body of law that has given it more definition and content than the phrase "manifestly unreasonable."118 It is interpreted in most jurisdictions to mandate a judicial process involving two separate findings, with one necessarily preceding the other. ${ }^{119}$ To declare a contract unconscionable, a court must first find a flaw in the bargaining process, followed by a finding (by the court, not a jury ${ }^{120}$ that the challenged provision is unfair. ${ }^{121}$ Unlike under the manifestly unreasonable concept, a judge does not simply second-guess the terms of the contract by making a judgment of fairness or reasonableness. Instead, a breakdown in the bargaining process must first be established. ${ }^{122}$

\footnotetext{
judged by the time of contracting.

(emphasis added).

114. Id.

115. See Trailmobile Div. of Pullman, Inc. v. Jones, 164 S.E.2d 346 (Ga. Ct. App. 1968).

116. U.C.C. \& 2-302 (1989).
}

117. See Authur Allen Leff, Unconscionability and the Code-The Emperor's New Clause, $115 \mathrm{U}$. PA. L. REV. 485 (1967). Among other things, Professor Leff's article contains a careful and comprehensive review of the legislative history of $\$ 302$.

118. See U.C.C. \$ 2-302 cmts. 1-3 (1989); Leff, supra note 117; see generally M.P. Ellinghaus, In Defense of Unconscionability, 78 YALE L.J. 757 (1969); Richard A. Epstein, Unconscionability: A Critical Reappraisal, 18 J.L. \& ECON. 293 (1975). A list of other articles is contained in FARNSWORTH, supra note 91 , at 324.

119. This is sometimes referred to as procedural (a flaw in the bargaining context) and substantive (an unreasonable, unfair term) unconscionability. This terminology was first used in Leff, supra note 117 , at 487 , and has enjoyed considerable use since then. It expresses well the underlying premise of the doctrine, which endorses the bargain principle. That is, until a court finds a flaw in the bargaining process, the contract reached by the parties is entitled to enforcement by the court without regard to the judge's views about the reasonableness and fairness of its terms.

120. U.C.C. $\& 2-302$ (1989) expressly mandates that the unconscionability decision be made by the court. This enhances the prospects for development of a body of law that has more focus and definition to it than can ever be achieved by jury decision under a reasonableness standard.

121. For a well known expression of this concept, see Williams v. Walker-Thomas Furniture Co., 350 F.2d 445, 449 (D.C. Cir. 1965): "Unconscionability has generally been recognized to include an absence of meaningful choice on the part of one of the parties together with contract terms which are unreasonably favorable to the other party." This sentence has been described as "the most durable dictum on the meaning of "unconscionability."' FARNSWORTH, supra note 91, at 332. Farnsworth also states that, "There has been relatively little refinement of this description." Id.

122. This does not mean simply an imbalance in the bargaining power of the contracting parties. Although the author has argued that partners ordinarily occupy positions of near-equal bargaining power (see supra text accompanying note 55), this was not intended to suggest that the existence of an 
The unconscionability doctrine does not work perfectly, but it is designed to insulate a bargain from "roving commissions"123 judging terms without regard to the bargaining status of the parties. ${ }^{124}$ It is thus more consistent with the bargain principle than is a general standard of "manifestly unreasonable."

In addition to the doctrinal distinctions noted above, one can point to the shock value of the word "unconscionable" as a point of difference between the two tests. ${ }^{125}$ It is true that both tests are aimed at the same problem: overreaching contract terms. There may also be room in the doctrine of unconscionability for a refusal to enforce a term of a contract on the basis of the sheer excess of overreaching involved, without reviewing the bargaining context. ${ }^{126}$ Nevertheless, "unconscionable" defines a more extreme situation that the milder "manifestly unreasonable." By doing so, it elevates the stakes and enhances the inquiry. That in turn accords greater respect to the agreement. ${ }^{127}$

imbalance in bargaining power constitutes a breakdown in the bargaining process. See U.C.C. $\$ 2-302$, $\mathrm{cmt}$. 1 ("The principle [of unconscionability] is one of the prevention of oppression and unfair surprise and not of disturbance of allocation of risks because of superior bargaining power."). The assertion of near-equal bargaining power is intended merely to underscore the presumptive validity of a bargain among partners, not to identify a condition for valid contracts.

123. See Epstein, supra note 118, at 294.

124. This does not mean that the bargaining context is never relevant to a decision as to "manifestly unreasonable," nor that it is always determinative in a decision as to unconscionability. It is undoubtedly true that some courts will look to the situation of the parties in a "manifestly unreasonable" case, but one rarely finds a court referring expressly to that. And in some unconscionability cases the courts make no reference whatsoever to bargaining context, sometimes on the ground that the unfairness of a term is so patent that the court apparently presumes a flawed bargaining contest. In a footnote in Williams, the court noted the possibility that extreme overreaching in an agreement can in itself raise a presumption of a flaw in the bargaining process:

Inquiry into the relative bargaining power of the two parties is not an inquiry wholly divorced from the general question of unconscionability, since a one-sided bargain is itself evidence of the inequality of the bargaining parties. This fact was vaguely recognized in the common law doctrine of intrinsic fraud, that is, fraud which can be presumed from the grossly unfair nature of the terms of the contract. See the oft-quoted statement of Lord Hardwicke in Earl of Chesterfield v. Janssen, 28 Eng. Rep. 82, 100 (1751): “. . . [Fraud] may be apparent from the intrinsic nature and subject of the bargain itself; such as no man in his senses and not under delusion would make. ..."

350 F.2d at 449 n.7 (alterations in original). One could ask what difference exists between "intrinsic fraud" and "manifestly unreasonable." The difference is one of degree. "Manifestly unreasonable" involves a judgment as to reasonableness, on which fair-minded people can differ. The doctrine of intrinsic fraud, on the other hand, involves a situation so extreme that it would shock and repel all fairminded people.

125. With regard to the root meaning of the word "unconscionable," see Leff, supra note 117 , stating, after noting in the text that the word unconscionable is pejorative:

As one would expect from its linguistic structure alone, which is the negativing of the root concept of "conscience." See WEBSTER, NEW INTERNATIONAL DICTIONARY OF THE ENGLISH LANGUAGE 2763 (2d ed. 1957). The examples of its use collected in 11 OXFORD ENGLISH DICTIONARY U-99 (1933) show the word to have been used through the ages as a rather generalized pejorative intensifier, a wide-gauge "snarl word." See HAYAKAWA, LANGUAGE IN ACTION 76-79 (1941).

Leff, supra note 117 , at 487 n.10.

126. See supra note 124 .

127. An analogy can be drawn from another uniform act recently promulgated by the NCCUSL. The Uniform Premarital Agreement Act address agreements between persons about to get married. An imbalance in bargaining power is more readily presumed under those circumstances than in 


\section{V \\ CONCLUSION}

RUPA has made many improvements in the law of partnership, as the other articles in this symposium demonstrate. It also has taken an innovative approach to one of the most important aspects of the partnership relationship, that of fiduciary duties. The overall tenor of the Act and of the literature produced by the drafters of the Act reflects genuine concern for the freedom of partners to define their relationship as they choose through bargaining, on the reasoning that the contractual nature of the partnership relationship is paramount. In that respect, RUPA goes further than most uniform legislation in recognizing the bargain principle and the status of partners as unusual fiduciaries who act for themselves as well as on behalf of others, and have a personal stake in profits.

Although those drafting RUPA recognized these principles and tensions, they were unable to break completely away from the temptation to mandate certain duties. Succumbing to this temptation is understandable, considering the desire to protect the unsophisticated from sharp dealers and the recognition of the limited foreseeability of the damage an abusive partner can do. To resist this and to urge near-total freedom of contract does not come easily to this author. But the presumptively equal bargaining power of the parties when entering into a partnership agreement, the powers and rights of partners (including the right of control and the power of at-will dissociation), and the indirect incentive of regard for one's reputation provide support for greater freedom of contract. When coupled with a duty of good faith, eliminating mandatory fiduciary duties will allow efficient agreements with maximum certainty for most partnerships.

conventional business arrangements. But rather than police such agreements by a "manifestly unreasonable" standard, the Act expressly adopts an unconscionability standard. UNIF. PREMARITAL AGREEMENT ACT $\$ 6(\mathrm{a})(2)$ (c) (last amended 1983), 9B U.L.A. 376 (1987). This strongly supports an unconscionability standard in RUPA, which addresses a relationship of marginal social interest and of presumptively equal bargaining power. 